\title{
MODERN VIEW OF SPEECH READINESS FOR SCHOOL OF CHILDREN OF OLDER PRESCHOOL AGE WITH TYPICAL PSYCHOPHYSICAL DEVELOPMENT AND SPEECH DISORDERS
}

\section{O. Bielova}

A theoretical review of modern scientific sources on the problem of "speech readiness" for the schooling of older preschool children with typical psychophysical development and speech disorders is presented. The aim of research: analysis of modern research on speech readiness for the schooling of older preschool children with typical and speech disorders. The objective of research was to substantiate scientific sources on the study of the terms "speech readiness" and "speech preparation" for school in older preschoolers; determination of components of speech readiness of children of older preschool age with speech disorders.

It is established that there are different views on the definition of the terms "speech readiness" and "speech training". Speech readiness for the school includes children's mastery of grammatical, lexical norms of speech, enriched vocabulary, use in educational and everyday activities of various functions of speech; it is determined that speech readiness contributes to the process of speech preparation of the future student to master the school curriculum. Speech training involves general and special training. It was determined that the formation of basic intellectual, semiotic and regulatory components is necessary for the speech readiness of children with speech disorders, which are formed under the influence of a special complex of correctional and developmental speech therapy work. Based on the analysis of scientific sources, the components of speech readiness for the schooling of older preschool children with speech disorders were identified: cognitive is about understanding of the semantic constructions of language and speech; motivational is about understanding of social and cognitive motives of learning; the component of activity - active participation in various types of speech activity; emotional - verbalization of emotions and feelings

Keywords: speech readiness, speech training, general speech training, cognitive component, children of older preschool age

Copyright (C) 2021, O. Bielova.

This is an open access article under the CC BY license (http://creativecommons.org/licenses/by/4.0).

\section{Introduction}

Speech readiness for school is a topical issue in preschool education. Each historical period, conditions of social life, educational opportunities dictated their model of education and upbringing of preschool children. Speech readiness is an important component of future first-grader. Once in the new educational and information space, the child at the verbal level has to actively perceive (phonemic auditory analysis), process (coding into internal speech), learn (dictionary) and use (grammatical design, etc.) in practical speech activities new material. In addition, becoming a participant in the learning process requires communication skills to work with peers and teachers. Unformed speech readiness, for various reasons (social neglect, various types of disease, impaired speech development, etc.), in preschool-age affects children's learning of the curriculum and relationships in the children's team. Therefore, the theoretical analysis of the study will identify the main components of speech readiness of older preschool children with speech disorders, which must be formed in preschool education.

\section{The aim and objectives of research}

The aim of research is to analyze modern research on speech readiness for the schooling of older preschool children with typical psychophysical development and speech disorders.
To achieve this aim, the following objectives were set:

1) substantiation of scientific sources on the study of the terms "speech readiness" and "speech preparation" for the school of older preschoolers;

2) determination of components of speech readiness for children of older preschool age with speech disorders.

3. Scientific and theoretical analysis of speech readiness for the schooling of older preschool children

In modern scientific publications, the concepts of "speech readiness" and "speech preparation" for the schooling of older preschool children are separated. In particular, "speech readiness" is seen as the mastery of children's grammar, vocabulary, forms (external, internal, dialogical, monologue) and functions (communication, planning, generalization, evaluation, etc.) of speech.

The readiness of the future student contributes to the result of the process of preparation for educational activities at school. A. Bogush [1], L. Kalmykova [2] reduced the understanding of speech training of future students to two main positions: general and special. Thus, general speech training begins at birth and lasts until the older preschool age. Its maturity is indicated by the level of perception and understanding of speech by children in the process of correlating their language units with objects and phenomena, with the connections and 
relations that exist between them. According to A. Bogush [1], such training presupposes sufficient speech adaptation of older preschoolers to the conditions of schooling.

Special speech training is mostly propaedeutic in nature - an initial reflection on speech material (initial awareness of the sign system, the formation of writing skills, reading, analysis of linguistic phenomena). It is divided into the language (cognitive-reflex) and speech (communicative-reflex) preparation of senior preschoolers for school. In particular, language (cognitive-reflex) includes in its activities a cognitive component, the basis of which are operations (analysis, synthesis, comparison, abstraction, generalization) and forms (judgments, inferences, concepts) of thinking; reproductive and creative imagination; the process of comprehending, memorizing and reproducing speech information.

Speech (communicative-reflex) involves the formation of children's various speech functions, communicative forms that provide the level of their awareness and are subject to further automation and its inclusion in a more complex speech action - speech skills. Whereas in general training speech is learned at the level of imitation or by the method of "trial and error".

L. Kalmykova [2] proposes to conduct speech training throughout preschool childhood, to reduce it to the natural conditions of communication: through the introduction of children into the language situation and their perception of the communicative process. According to her, such training will help future students to gain experience and skills to navigate in the speech environment.

K. Krutiy [3] substantiates the "speech training" of preschoolers at the level of complex use of language and non-language means of communication by the child; units of speech for mental activity, communication and awareness of one's personality in the process of life. The child is a subject of speech activity, who with the help of adults accumulates and improves new knowledge, skills and abilities. The scientist describes four areas of speech education of preschoolers: linguistic (formation of knowledge of phonetics, vocabulary, grammar and syntax of the Ukrainian language); speech activity (speech activity in various forms of activity); communicative (development of communication taking into account speech capabilities); national-cultural (national and foreign cultural heritage).

In the process of preparing children for school, A. Bogush [4] considers speech learning under the prism of speech and artistic speech activity, which is grouped on the principles of continuity and perspective. Speech training according to her teaching includes the formation of oral speech skills in an older preschooler and their use of speech units in thinking, communication; awareness of the sign system of speech for their mastery of writing and reading. According to the scientist, before entering school, a child should have developed a set of speech components: sound pronunciation, phonetic perception, vocabulary, coherent speech, the grammatical structure of speech, reading. The scientist pays special attention to the formation of evaluation-controlled actions in a speech to prepare a six- to a seven-year-old child for school. According to her, they provide conscious regulation of speech activity, in order to prevent, diagnose and correct errors in speech.

According to N. Pakhomova [5], speech training should be considered as an integrated result of general speech and special language training, which will provide older preschool children with speech readiness, the formation of practical speech skills, improvement of communicative forms and functions of speech activity.

Speech training according to the scientist has carried out in two directions: 1) speech readiness (formation of oral speech, correct sound pronunciation, grammatical structure, lexical stock, phonetic perception, sound analysis of words); 2) communicative readiness (use of verbal and non-verbal means of communication), which means the acquisition of speech and communicative competence, which will contribute to the mastery of the school program by preschoolers [5].

According to L. Kalmykova [6], T. Pirozhenko [7] and others, children's readiness for school depends on their communicative and speech formation. Speech, according to scientists, establishes social ties between the child and the people around it; carries out reception and transfer of information reality; becomes a regulator of behaviour, and accordingly means of education and training.

From the standpoint of T. Pirozhenko [7], creating and ensuring the integrity of communicative connections between the child and its environment (child-adult, child child, etc.) allows forming its speech competence. The scientist identified tasks for the development of communication and speech skills in preschool children, which include: the formation of forms (emotional-personal, situational-business, extra-situational) and means (nonverbal, verbal) of communication; differentiation of feelings (aesthetic, moral, intellectual), for a holistic speech relationship between adults and peers; development of the cognitive activity, intellectual abilities; formation of a creative approach to activities and communication.

In the process of studying the formation of speech readiness of older preschool children to study at school N. Shilina [8] experimentally proves the effectiveness of the influence of pedagogical conditions such as communicative-speech orientation in learning; use of speech in different areas of educational activities (cognitive, speech, artistic, theatrical, game, communicative); an integrated approach to speech learning and development; formation of adequate motivation for communicative and speech activity; cooperation with parents to work on enhancing the communicative and speech development of children. In addition to "speech readiness", the researcher consideres the main directions of speech preparation of children for school in preschool.

For the formation of speech readiness D. Lebedenko, I. Kuzava [9] propose to correctly select methods and techniques for speech development, to activate the acquired speech skills, to combine verbal and visual teaching methods, to consolidate the acquired experience of language communication. Paying attention to the individual characteristics of the development of older preschool children, the educator should enrich and encourage children's speech activity. According to the authors, this approach will provide a positive impact on the over- 
all development of the child and also prepare it for further education at school.

L. Grigorieva [10] consideres the effectiveness of the process of forming the speech readiness of preschoolers to study at school through pedagogical support. For her reasons, the teacher's interaction with the child at the level of subject-subject relations (taking into account the child's self-esteem, emotional openness, invaluable perception of the child, etc.) allows children to form cognitive-speech processes, ability to analyze, evaluate their own speech, improve communication skills. The scientist developed a design unit of the model which includes pedagogical conditions and stages of speech readiness formation. The developed model of pedagogical support included factor (requirements of state education) and formative (through components of speech readiness) parts which reflected interrelation of blocks (target, pedagogical support, design, realizing, analytical and effective) and components (motivational, cognitive, activity).

In her scientific work, the scientist considers socio-cultural factors that affect speech readiness, namely: public institutions - children's preschools, schools, media, publishing houses, cinemas, theatres, etc .; family creating an emotionally pleasant situation for the emergence of desires to participate in communication; information technology - building a specific communicative environment - the child experiences screen dependence, is under the influence of a chaotic flow of negative information, which limits communication and leads to emotional discomfort; deterioration of children's health affects the cognitive and speech development of preschool children.

It highlights the components of speech readiness such as motivational, cognitive and activity. In particular, learning motivation consists of cognitive, social motives for learning, as well as motives for achievement, which provides the necessary level of arbitrary organization of behaviour and activities. The author notes that the need for communication is a powerful factor that affects the speech readiness of children and is necessary for the successful formation of motivational readiness for school.

The essence of the cognitive component of speech readiness consists of "preschooler awareness of the phenomena of language and speech and the development of speech abilities, i.e, the accumulation of aggregate speech knowledge, skills and abilities that allow her to understand and build new statements according to the speech situation and rules adopted in this language for the expression of opinions".

L. Grigorieva [10] centralizes on the works of T. Babayeva [11] and M. Lvova [12], which highlight another key component of the formation of speech readiness of preschoolers - activity. From their point of view, it is necessary to create pedagogical conditions for the development of independent children's experience. All this should be based on the principles of integration of general educational nature, interconnection and complementarity of different types of children's activities, their only focus on the development of independence, initiative, creativity, cooperation and accumulation of social skills.

The main rule of pedagogical support, according to the author, is to enable the preschooler to overcome another obstacle, while forming intellectual, moral, emotional, volitional potential to feel like a person who is capable of actions and independent decisions.

Developed speech skills indicate the holistic mental development of children. A. Shishkina [13] point out that the speech development of preschoolers involves the formation of oral speech and speech communication skills based on mastering literary speech: "... mastering speech as a means of communication and culture; enrichment of the child's active vocabulary; development of coherent, grammatically correct dialogic and monologue speech; development of speech creativity; acquaintance with book culture, children's literature, listening to texts of different genres of children's literature; formation of sound analytical-synthetic activity as a prerequisite for literacy; development of sound and intonation culture, phonemic hearing".

According to her, the main components of speech readiness are timely vocabulary development and speech abilities. The author pointed out that"... children, who do not have sufficient vocabulary, have great difficulty in learning, they find it difficult to find the right words to express their thoughts", "... students with a rich vocabulary better solve arithmetic problems easier to master reading skills, grammar...".

Possession of speech, according to S. Privalova [14] is a mean of knowing reality. The more a child learns the richness of language, the more freely he/she uses it, the better he learns the complex connections in nature and society. "For a child, literate speech is the key to successful learning and development." But the author also notes that the development of speech activity can not develop spontaneously, it requires appropriate pedagogical influence.

S. Privalova [14] adds that it is in preschool-age that speech functions are laid down, which are important for the formation of intelligence, in particular, the communicative function of speech affects the intellectual and emotional development of children (in communication is learning new speech concepts); cognitive function of speech is responsible for the preschoolers' perception of the surrounding information (with the help of sensory function there is a search activity, the development of verbal memory, which is supported by the development of generalized thinking); regulatory function allows the child to carry out internal planning of intellectual activity).

G. Kokkalia, A.Drigas, A.Economou, P. Roussos [15], P. Williams, M. Lerner [16] and other scientists note that difficult living conditions (upbringing, poverty, violence, inadequate or dysfunctional socialization) condition (developmental delay, disability, trauma, chronic diseases), inherited characteristics (abilities, temperament, personality) and various combinations of these factors affect the level of both general and speech readiness of the child for school. S. Pekdoğan, E. Akgül [17] in their study note that the child's speech readiness for school is significantly influenced by preschool education, family upbringing, learning and the environment of the preschooler. There should be a single approach in speech readiness for school between educators and parents. That will allow forming educational motivation, emotional balance for school conditions. 
The results of research by such scientists as S. Foster-Cohen, A. Bysterveldt [18], L. Trofimenko [19], etc., indicate that the immaturity of speech activity in preschool-age naturally leads to reading and writing disorders. Insufficient level of children's speech readiness for school causes persistent and severe difficulties in learning the material, as well as the underdevelopment of regulatory and communicative functions of language.

A. Yakovenko [20] points to the lack of components (basic intellectual, semiotic and regulatory) of speech readiness in children with phonetic-phonemic speech underdevelopment and with general speech underdevelopment of primary genesis of the III level. She developed a program-methodical complex of correctional and developmental speech therapy work on the formation of speech readiness for the school of senior preschoolers with speech pathology. But the components of speech readiness for schooling such as cognitive, motivational, emotional and activity in these scientific papers have not been thoroughly studied.

\section{Results}

The substantiation of the presented scientific theoretical-methodological and practical developments reveals the ontogenesis of children's speech development. In the scientific approach to the problem of our study, we are based on the main parameters of development of older preschool children, in which the basic components of speech readiness should be formed for schooling: cognitive, activity, motivational, emotional. In particular, cognitive (intellectual-speech) - covers the idea of the semantic constructive significance of language and speech, the formation of speech components:

- phonemic perception (distinguishing acoustically close sounds by ear; sound analysis and word synthesis, etc.);

- sound pronunciation (the correct pronunciation of all sounds of the native language in words, etc.);

- vocabulary (correct use of words in speech, the ability to generalize them, select synonyms, antonyms, use in the speech of nouns, adjectives, numerals, verbs, adverbs, pronouns);
- grammatically correct expression of their own opinions, maintaining a conversation, building communication-based on the situation; formed coherent and prosodic speech (mastery of intonation, volume and tempo of speech).

Motivational (learning motive) is about the understanding of social and cognitive motives of learning, their arbitrariness in the organization of behaviour and during learning. Activity (speech activity) is about active participation in various types of speech activity, a manifestation of independence, creativity, initiative, cooperation with children and teachers. Emotional (verbalization of emotions and feelings) - awareness and control of their emotional state, adequate expression of emotions in various life situations, the ability to explain and recognize them in other people.

\section{Conclusions}

Analysis of the theoretical study of the problem of speech readiness for the school of older preschool children with typical psychophysical development and speech disorders showed:

1) in psychological and pedagogical sources the terms "speech readiness" and "speech training" have different meanings. In particular, "speech readiness" for school involves the mastery of older preschoolers grammatical, lexical norms of speech, enriched vocabulary, the ability to use in practice the various functions of speech; it is revealed that "speech readiness" provides the process of "speech training", the structure of which includes general and special speech training; determined that the "speech readiness" of children with speech disorders requires the formation of basic intellectual, semiotic and regulatory components, which are formed under the influence of a special set of correctional and developmental speech therapy work.

2) the components of speech readiness for the schooling of children of senior preschool age with speech disorders are allocated on the basis: cognitive - understanding of semantic constructions of language and speech; motivational - understanding of social and cognitive motives of learning; activity - active participation in various types of speech activity; emotional verbalization of emotions and feelings.

\section{References}

1. Bohush, A. M., Havrysh, N. V. (2015). Doshkilna linhvodydaktyka: Teoriia i metodyka navchannia ditei ridnoi movy v doshkilnykh navchalnykh zakladakh. Kyiv: Slovo, 704.

2. Kalmykova, L. O. (2016). Formuvannia u ditei starshoho doshkilnoho viku movlennievoi diialnosti: diahnostykorozvyvalnyi kompleks. Kyiv: Slovo, 384.

3. Zdanevych, L., Kruty, K. (2019). Overcoming Communicative Deadaptation of Speech Passive Children of Pre-School Age. Psycholinguistics, 26 (1). doi: http://doi.org/10.31470/2309-1797-2019-26-1-141-159

4. Bohush, A. M. (2017). Metodyka rozvytku movlennia i navchannia ridnoi movy ditei rannoho viku. Kyiv: Slovo, 392.

5. Pakhomova, N. H., Sheremet, M. K. (2009). Formuvannia movlennievoi hotovnosti ditei starshoho doshkilnoho viku z dyzartriieiu do navchannia v shkoli. Kyiv, 137.

6. Kalmykova, L. O., Kyuchukov, H. (Ed.) (2015). Ontogenesis of the vocal activity of children of the sixth year of life. Acquisition of Slavic Languages. Munich: Lincom, 29-53.

7. Pirozhenko, T. O., Soloviova, L. I. et. al. (2016). Tsinnisni oriientatsii dytyny u doroslomu sviti. Kyiv: Slovo, 248. Odessa.

8. Shylina, N. Ye. (2003). Formuvannia movlennievoi hotovnosti ditei starshoho doshkilnoho viku do navchannia u shkoli.

9. Lebedenko, D., Kuzava, I. (2018). Features of the use of techniques and methods for the development of speech of children of senior preschool age. Pedahohichnyi chasopys Volyni, 4 (11), 112-116.

Tver, 194

10. Grigoreva, L. V. (2013). Pedagogicheskaia podderzhka formirovaniia rechevoi gotovnosti detei k obucheniiu v shkole. 
11. Babaeva, T. I. (2005). Problema sotsialno-nravstvennogo vospitaniia i razvitiia rebenka v issledovaniiakh kafedry doshkolnoi pedagogiki. Gotovnost k shkole kak pedagogicheskaia problema. Pedagogika detstva: Peterburgskaia nauchnaia shkola. Saint Petersburg: RGPU.

12. Lvov, M. R. (2000). Osnovy teorii rechi. Moscow: Akademiia, 248.

13. Shishkina, A. S. (2016). Rechevaia gotovnost k shkole detei predshkolnogo vozrasta. Molodoi uchenii, 24 (128), 560562. Available at: https://moluch.ru/archive/128/35469/

14. Privalova, S. E. (2018). Teoriia i praktika komunikativno-rechevogo razvitiia detei doshkolnogo vozrasta. Ekaterinburg: Ural. gos. ped. un-t, 192.

15. Kokkalia, G., Drigas, A. S., Economou, A., Roussos, P. (2019). School Readiness From Kindergarten to Primary School. International Journal of Emerging Technologies in Learning (iJET), 14 (11), 4. doi: http://doi.org/10.3991/ijet.v14i11.10090

16. Williams, P. G., Lerner, M. A. (2019). School Readiness. Council on early childhood and Council on school health. Pediatrics, 144 (2). doi: http://doi.org/10.1542/peds.2019-1766

17. Pekdogan, S., Akgul, E. (2016). Preschool Children's School Readiness. International Education Studies, 10 (1), 144 154. doi: http://doi.org/10.5539/ies.v10n1p144

18. Foster-Cohen, S. H., van Bysterveldt, A. K. (2016). Assessing the communication development of children with language delay through parent multi-questionnaire reporting. Speech, Language and Hearing, 19 (2), 79-86. doi: http://doi.org/10.1080/ 2050571x.2015.1108067

19. Trofymenko, L. I. (2016). Speech Development Of Preschool Children In The Conditions Of Inclusive Education. Osvita osib z osoblyvymy potrebamy: shliakhy rozbudovy, 11, 211-216.

20. Yakovenko, A. O. (2018). Formuvannia movlennievoi hotovnosti starshykh doshkilnykiv z lohopatolohiieiu do intehrovanoho navchannia. Kyiv, 330.

Received date 17.12.2020

Accepted date 22.01.2021

Published date 30.01.2021

Olena Bielova, PhD, Associate Professor, Department of Speech Therapy and Special Techniques, KamyanetsPodilskyi Ivan Ohiienko National University, Ohienko str., 62, Kamyanets-Podilskyi, Ukraine, 32300

E-mail: alena.bielova77@gmail.com 